\title{
The changing language of social policy in Hungary and Poland
}

\author{
Zsófia Aczél, Dorota Szelewa and Dorottya Szikra
}

The modern history of Hungary and Poland, both belonging to Central and Eastern Europe (CEE), is characterised by turbulent political and economic changes and 'emergency' decisions in the field of social policy (Inglot, 2008). Forty years of an autocratic communist regime provides the strongest common legacy of social policy in the two countries. The subsequent liberal democracies, built up since 1990, have, however, brought to the surface long-forgotten patterns of midwar social policy in both countries which now shape the language of social policy, together with that from their communist legacies. The neoliberal agenda of 'retrenchment' has penetrated Eastern European countries just when they were about to adjust their welfare institutions to capitalist democracy, making a strong impression on their social policy agendas and languages. During the process of accession to the European Union (EU), Poland and Hungary also adopted some of the social policy discourse of the EU, though not without controversies. The historical volatility of social policy programming in this region (Szikra and Tomka, 2009) is partly due to the sharp ideological division on this matter between Conservative and Socialist elites. This is why the issue of social policy, as we argue in this chapter, has been politicised ever since the introduction of the first state-run programmes. This is reflected in the translation of 'social policy' into both Polish and Hungarian, in relation to which we need to make a key remark right at beginning of our chapter: there is only one word for 'policy' and 'politics' in Hungarian and Polish, as both are called 'politika' (in Hungarian) or 'polityka' (in Polish). Thus the term 'social policy' has most often been translated as 'szociálpolitika' in Hungarian and 'polityka społeczna' in Polish.

In this chapter we demonstrate how historical legacies since the late 19th century - together with current internal, external and supranational influences - have formed the distinct social policy languages in these post-communist countries. Key terms and definitions 
used to describe the field and aims of social policy are investigated in the most important periods during which distinct developments in social policy language have been witnessed: first, from the late 19th century to the Second World War; second, from the state socialist period (late 1940s) to 1989; and third, from the eve of the political and economic transformation in 1989/1990 up until today.

\section{From the late I 9th century to the end of the Second World War}

Hungary had partial autonomy within the Austro-Hungarian Empire from 1867 to 1920, when the Monarchy fell to pieces. Poland, at the same time, was carved up between Russia, Prussia and Austria, with a few enclaves of self-government, of which most were within the Austrian part (Galicia). In both countries, the emerging official social policy language was linked to a Bismarckian type of social insurance with strong German influence on the language of social policy.

The Hungarian state was eager to establish social insurance schemes compatible with the Austrian and German legislation of the time (Szikra, 2004). The language of the first social insurance legislation (Act XIV of 1891 on Sickness Insurance) mimicked that of the Austrian and German model as it was almost a word-for-word translation of relevant German language legislation. Similarly, in the Austrian part of Poland (Galicia) - which had more autonomy within the Habsburg Empire - several laws were taken from Austria (including the system of social insurances introduced in 1888), with the principles of subsidiarity and merit governing the distribution of welfare (Jakubiec, 2007). The process of transposing social policy legislation was facilitated by the widespread use of German in the multi-ethnic Austro-Hungarian Monarchy, where this language was used not only by the state apparatus but quite frequently by ordinary people. The independent Ministries of the Hungarian Kingdom only gradually changed their working language to Hungarian during the late 1880s and early 1890s, and used both languages for a short while.

Such German language domination was not the case in the Russian part of Poland, where, importantly, the basis for welfare entitlements was not predominantly insurance, but where welfare institutions targeted the poorest. Here the overall public administration was much less willing to build social security systems (Zalewski, 2006). In contrast, in the Prussian part's policies were typically centralised, based on the laws binding all the inhabitants of German lands. They were also highly bureaucratised and involved direct citizen control. 
Already at this time, the development of a social policy vocabulary was taking place in these two countries with different understandings and connotations. In Hungary, the term 'social policy' (szociálpolitika) was used first and foremost as a synonym for 'workers' insurance' (munkásbiztositás). The word 'worker' clearly referred to 'industrial worker', and not to 'agricultural worker'. The first social insurance legislation was called 'workers' assistance' (munkássegélyezés). This labelling shows the uncertainty of social policy language: there was no clear distinction yet between 'social insurance' and 'social assistance'. The second meaning of 'social policy' was 'workers' protection', or 'work protection' (munkavédelem), mainly from injuries, the enactment of which dates back to 1893, when a list of 'dangerous' industries was defined and related regulation of production was formulated (Bódy, 2011). The most important actors who influenced decision making on social policy - state bureaucrats as well as employers' and labour organisations - agreed that the state should not interfere with industrial affairs more than it did through the compulsory social insurance legislation. The relationship between the state and the economy was clear: the limits of social policy were set at a few percentage points of compulsory social insurance contributions, and very limited social assistance benefits were provided at the municipal level. This liberal approach was gradually replaced by the idea of a more interventionist state during and after the First World War (WWI), broadening the meaning of social policy and changing its language respectively.

The dividing line between two basic understandings of social policy in Poland was the scope of social policy. Polish intellectuals who eventually became the architects of the Polish welfare state after 1918 developed different social policy meanings and emphasised different priorities. A narrower, Bismarckian approach to social policy emphasised entitlements based on 'social insurances' (ubezpieczenia społeczne) as the basic response to the 'social question' (Soziale Frage) (Orłowski, 1912; Rysz-Kowalczyk, 2002). Others understood 'social policy' in a broader sense: as the overall policy approach for shaping social relations. An influential intellectual and feminist activist, Zofia Daszyńska-Golińska, wrote a brochure in which she defined 'modern' social policy in contrast to the term 'economic policy', thus criticising 'classical', market-oriented economic thought. Here 'social policy' (polityka spoteczna) is understood very broadly, in the context of human rights. She also defined the group of intellectuals working on social policy concepts as 'the new school of social politicians' (politycy społeczni) and historical economists, also called 'socialists ex cathedra' (DaszyńskaGolińska, 1906: 6). However, while Hungarian social policy language 
had already developed as a part of official public policy vocabulary, these developments in the Polish land took place within the independence movement, and often beyond formal policy making.

Following the loss of the war in 1918, the Austro-Hungarian Monarchy fell apart and two thirds of the previous territories of the Hungarian Kingdom were taken away as a punishment. After the social democratic revolution in 1918 and a short communist dictatorship in 1919, a long period of Conservative rule started where the 'left' was pushed to the margins. Linked to the fear of the potential 'disappearance' of the Hungarian nation and the wish to regain lost territories, a nationalist discourse on social policy emerged. At the same time, with the end of the Great War, Poland regained independence. As early as 1918 Parliament adopted several important laws on labour relations and social security provisions. This made the Polish social security system one of the most developed in Europe (Czubinski, 1978; Albert, 1989). As Poland signed the Washington Treaty and joined the International Labour Organization (ILO) in 1919, the Constitution that was finally adopted in 1921 needed to include many important social rights. In contrast to the Hungarian case, where the right-wing parties were in a ruling position during the mid-war period, the Polish social policy agenda was dominated by the Socialists, especially in the first, critical phase of welfare state development following the years when independence was achieved.

Importantly, independence meant establishing a central administration that would bring Polish social policy research which had been carried out 'underground' to the documents and language of official public policy. The first central administration unit that was engaged in social policy issues was named the Ministry of Labour and Social Welfare (Ministerstwo Pracy i Opieki Spotecznej).In fact, the term 'opieka społeczna', used in the Ministry's name, could also be translated as 'social care' and understood in a broader sense: as the overall state effort (administered by this powerful Ministry) to 'protect' society against different social risks and to 'take care' of the inhabitants of the fledgling Polish state. This was also in line with the holistic philosophy of encompassing social policy as a state project and illustrated the paternalist role of the state. As noted by Inglot (2008), social policy (social 'care') was more directly part of a statist philosophy in Poland than in other countries of the region. The role of social policy was also to support the statebuilding project and was interrelated with the issue of (national) economic growth (Zawadzki, 1927). Overall, though, the language of official documents, especially in the Ministry of Welfare, included 
the use of terms such as 'struggle of the working class', 'exploitation', 'social justice', 'equality', and 'social progress'.

While the first years after WWI were important for the development of Polish social policies, in Hungary the important change came with the Great Depression of 1929, when the crisis boosted the idea that the state had to intervene in the free market for the purpose of the 'collective good' - even if it would be against the interests of individuals. This was closely linked to the nationalistic and Conservative politics of the interwar era, which abandoned the ideal of 'liberal' capitalist democracy. As the Minister of the Interior put it on the occasion of the opening ceremony of a 'social course' (szociális tanfolyam) for civil servants at the end of the decade: 'Instead of the unlimited ambition of the individual, the interest of the community has to come to the fore' thus 'the individual has to subsume his selfishness to the public' (Esztergár and Somogyi, 1940:13). Experts and bureaucrats now argued that previous social policies were 'fragmented' and thus a new, 'organic' social policy was needed, especially in the field of social assistance, which by this time became explicitly separated from social insurance (Esztergár, 1941).

The emblematic programme of this period in Hungary was the socalled 'Productive Social Policy' (produktív szociálpolitika, PSP), which aimed at the 'uplifting' of the agricultural poor through providing loans and organising 'welfare co-operatives' (Szikra, 2012). Social assistance was no longer a mere 'waste of money', according to PSP, but 'contributed to the inclusion of lower classes in the circle of production and consumption' from which the economy as a whole benefited (Esztergár, 1941). The word 'productive' had gender connotations in this context: 'meaningful employment' for men, and 'reproductive' roles for women. According to the nationalist ideology, it was not just coping with the poverty of agricultural workers, but the 'protection' of the ethnically defined 'Hungarian family and nation' (Indoklás, 1940) that was at stake with the success of the new programme, which was closely interlinked with anti-Semitic legislation (Szikra, 2009).

This ideological underpinning gave PSP a larger role in discourse than in practice. While the programme had a rather limited scope, affecting only a small number of impoverished agricultural families, it was celebrated as a manifestation of the newly designed Hungarian 'active' or 'social state' (szociális állam). The German 'Sozialstaat', as well as the Italian corporate state, served as models for the 'social state', an important feature of which was a new design of state bureaucracy. The state would be 'brought closer to the people' according to Zoltán Magyary, an influential expert on state bureaucracies (Magyary, 1939). 
Compulsory 'social courses' were organised for local bureaucrats to make them sensitive to the needs of poor people and, not least, to propagate the merits of productive social policy (Esztergár and Somogyi, 1940).

Finally, Poland also suffered from the economic crisis of 1929. But while in Hungary the government (as in other countries) developed more comprehensive social policies, the post-crisis era in Poland can be characterised by retrenchment affecting the generous policies that had been created after 1918. However, other changes came as well: the domination of the Socialists in governments was over after the coup d'état of May 1926, which was led by the powerful political leader Józef Piłsudski. Though Piłsudski originally belonged to the Socialist camp, he left the Socialists and became the leader of the right-wing political forces called the 'Sanacja' movement. Sanacja gained influence from the 1930s, as nationalist rhetoric increasingly gained ground in public policy. The political domination of Sanacja was also possible thanks to the quasi-authoritarian style of their rules: among Sanacja's methods of removing political competitors was sentencing and imprisonment of political opponents. However, in relation to social policy language, these processes did not bring about significant change. Although the word 'labour' disappeared from the name of the Ministry for Social Welfare in 1932 (thus signalling the strengthening of the 'protectionist' and 'paternalistic' role of the state together with a diminishing emphasis on 'class struggle'), the infamous Sanacja rules in fact managed to centralise social insurance funds in 1933.

These developments left Hungary and Poland with two sets of discursive legacies with regard to social policy language. While in Hungary the term 'social state', as well as its propagators, was pushed aside for several decades following the Second World War (WWII), the ideas of central planning, the scientific organisation of state bureaucracy, and state intervention in the economic system in the name of the 'collective good' were given a new lease of life under Communist rule. However, in Poland the legacy of the first, post-independence social policies - inspired by socialist and leftist thought - continued to influence social policy language for decades to come.

\section{State socialism}

After the Communist takeover, the two countries received perhaps the most 'unifying' impulse in their history, though with different outcomes in the early Communist times and in the later state socialist regime. 
The new 'soviet' model of social policy was implemented in different ways as it was confronted with different local conditions and legacies.

The period between the Communist turn (in 1949 in Hungary and 1944 in Poland) and the 1956 revolution in Hungary was that of a genuine Stalinist dictatorship in both countries (called 'Rákosiregime' in Hungary). The second period after the revolution (called 'Kádár-regime') was marked by a 'compromise' between the state and the citizens in Hungary, with substantial welfare efforts being made from the 1970s onwards. For Poland the period after 1956 could be further divided according to the party leadership of Władysław Gomułka (1956-70) and Edward Gierek (1970-80), while the early 1980s were dominated by the Solidarity protests followed by a decade of economic decline.

In Hungary, the totalitarian dictatorship was based on the personality cult of Stalin and his Hungarian follower Mátyás Rákosi. A command economy was introduced with the first three year plan in 1947, and the one party system, coupled with the almost total nationalisation of the industry, in the following years. The inclusion of women and agricultural workers in the production of heavy industry were the prime aims of the communist regime, not least due to the preparations for a possible Third World War (Romsics, 1999: 312). Compulsory employment had major effects on social policy, not only because social rights became closely entwined with employment in the 'state sector', but also because it was supposed that the command economy and full employment would together solve all previously existing social problems, including poverty. Roma people (being the largest minority in the country, with about $5 \%$ of the total population), the majority of whom were excluded from mainstream society before WWII, were to be integrated into society by taking up the lowest skilled jobs in heavy industry. The essence of the so-called 'economic turn' is best summarised by Welfare Minister Anna Ratkó, just before her Ministry was dissolved in 1950 (only to be re-established in 1991): 'All the acts of the state are social policy' (Ferge, 1986: 158).

Social policy and social work as independent disciplines were thus deliberately excluded from the vocabulary of the party elites, and from scientific research and education because they would have highlighted the existence of poverty and social problems which, in theory, did not exist after the 'economic turn'. 'Social care' (szociális gondozás), however, was still carried out by district nurses under the supervision of doctors and the Ministry of Health. 'Social policy departments' (szociálpolitikai ügyosztály) continued to exist in local councils: their task was to provide small amounts of social assistance to those unable to work, such as 
people with disabilities or who were marginalised. Social assistance was given a low profile and people with disabilities or mental health issues were hidden from the view of the general population so as not to destroy the image of communist rule.

At the same time in Poland - subsequent to policy decisions already made in the 1940s - the communist leaders focused on restoring social insurances (especially health services) that had already existed before the war (Jackowiak, 1991). Although the basic principles of the prewar social insurance system were sustained, they gradually came to cover new occupational groups. Social policy was subjugated to the goals of economic policy, and economic plans involved the prioritisation of developing the industrial sector. In the 1940s, a new system of the public health was created, which was coordinated by the newly established Ministry of Health and Social Welfare ('social care') and which shared responsibilities with the Ministry of Labour and Social Affairs (spraw socjalnych).

The introduction of such central planning was accompanied by a change in the social policy discourse. As early as 1947, the 'productivist' approach had become apparent: the very first assumption of social policy in the context of the command economy was to bring every person to work (women, people with disabilities and others). The role of 'social care'(opieka spoteczna) in a traditional sense was to become marginal; instead, the postulate was to 'make the social care institutions productive' (uproduktywnienie instytucji opiekunczych). This was justified on moral grounds: for example, the practice of pushing people with disabilities and dependent individuals into an economically passive role was 'hard to think of in a system ruled by the people' (ludowładztwo) (Orlewicz, 1947). The communist party regarded social insurances as a tool for increasing the physical fitness and readiness of employees to work in heavy and dangerous conditions, all according to the requirements set out in the central plan. Social care was, therefore, regarded as unnecessary and having an 'incapacitating' (ubezwłasnowolnienie) effect on people (Radlińska, 1947).

Importantly, the term 'socjalizm' in Polish and 'szocializmus' in Hungarian (labelling the state political and economic system) is closer to the narrower translation of social policy, (polityka socjalna; szociálpolitika) (Sozialpolitik). This narrower translation is also reflected in how the social programmes were functioning, to a large extent being transferred to the factories and workplaces. The expression 'socjalna' (narrow) instead of 'spoteczna' (broad, used in the first Polish social policy legislation) was also reflected in the name of the central ministry responsible for the coordination of these different social programmes. 
In both countries, social policy language developed as a part of the official propaganda, with the predominant role of the state (and party) as the decisive benefit provider. The state provided 'societal benefits', as translated from the Russian (társadalmi juttatások- социильные льготь), in a paternalistic manner, where the state, as father, 'made sacrifices for the building of Hungarian workers' democracy'. In the language of communist leaders, expressions like 'our state' (államunk) and 'our people' (népünk) were frequently used with the connotation of the leaders themselves 'owning' the state and the people. This language was neither professional nor personal: it resembled the language of armed forces mixed with bureaucratic clichés. ${ }^{7}$ In this way, the official language of policies, including social policy, became gradually distanced from the vocabulary of everyday people. Frequently used expressions served to delineate those who were 'building socialism' - and who belonged to the 'working class' (munkásosztály) - and those who were the so-called 'class aliens' (osztályidegen). The meaning of 'people' (nép) now marked the new society of 'socialist persons' (szocialista ember) whose place in the division of labour - rather than their social situation (their needs) - defined their social rights. The minority group of 'class aliens' was punished, not least through the means of social policy. For instance, privileges gained by civil servants in the prewar social insurance system were taken away; and agricultural workers not willing to enter state cooperatives did not receive free health care and sick pay and were excluded from receiving family allowance for years (Petô and Szakács, 1985; Ferge, 1986). As 'work' was put at the centre of 'building socialism' and was made the only basis of social rights, the legal category of 'publicly dangerous work-avoidance' (közveszélyes munkakerülés, $K M K$ ), which had already been established before WWII, gained special importance.

In a very similar manner, social policy programmes in Poland (programy polityki socjalnej) (so in a narrow sense) were put in place in favour of manual workers and the new category of intelligentsia: when describing the role of white-collar workers, the official propaganda made the distinction between the 'working intelligentsia' (inteligencja pracujaca) and those who were not state employees, and therefore not considered as working (or 'producing'). While the former were mostly white-collar employees of the state (secondary to the 'working class') and in this sense a 'good' and 'deserving' intelligentsia, the latter were regarded 'undeserving', were therefore excluded from any right to use

The prototype of George Orwell's 'Newspeak' in Nineteen Eighty-Four (1984) is exactly this totalitarian language. 
the privileges offered by the socialist state. As in Hungary, the notion of 'class enemy' (wróg klasowy) was used in relation to any actions undermining the legitimacy of the communist system (Chumiński, 2010). Importantly, Poland was the only country in the Soviet bloc where private farming was not eradicated through collectivisation. The existence of private land ownership was seen as 'alien' to the socialist economic order and had profound consequences for such farmers. The derogatory term 'kułak' (кулак) was used in propaganda with regard to the owners of larger farms in both countries and became the basis for inferior treatment, including reduced social policy entitlements.

Despite the compulsion to work, living standards in Hungary decreased relative to the 1930s (Ferge, 1986); thus the 1956 revolution in Hungary was partly a product of the social deprivation that the vast majority of the Hungarian population experienced. Following the suppression of the revolution, János Kádár's main invention was a 'welfare compromise' between party elites and the 'people', which led to an eventual increase in living standards and a decrease in inequalities as well as in poverty from the mid-1960s. The legitimacy of the system rested on increased wellbeing, which was based on the growth of centrally planned wages and low prices of basic goods, coupled with extending social insurance benefits. 'Strategic plans on social policy' were created from the early 1960s, thus the term 'social policy' reentered the political (but not yet the public and scientific) discourse. This is also indicated by the fact that such documents remained 'top secret', to be read only by ministerial and high-ranking political officials. The widest possible definition of social policy was present in such plans, including those relating to social insurance, housing policy, health care, wages, family policy (under the name of the 'population question') and even the issue of holiday resorts for workers (Munkaügyi Minisztérium, 1960).

By the late 1970s the central terms of Hungarian social policy discourse became 'societal welfare' (társadalmi jólét) and 'quality of life' (életszínvonal), while 'work' in the 'socialist sector' remained the basis of eligibility to social benefits. The word 'protection' also reappeared in relation to needy and deserving social groups such as children, older people and those with disabilities. However, 'protection' meant not only social protection of the vulnerable but also the protection of the socialist ideal from the reality of social problems. Institutions for children, older people and those with disabilities continued to exist in remote mansions in the countryside, hidden away from the eyes of the majority of society. 
In Poland the Stalinist phase was also over in 1956, and the country entered a period of 'small stabilisation' with the new leadership of Władysław Gomułka. The term 'social security' (zabezpieczenie społeczne) became more popular from late 1950s and early 1960s. The use of this notion was inspired by The Social Security Act of the New Deal legislation (1935), as well as by The Social Security Act of the Working People, issued by the Council of People's Commissars in revolutionary Russia in 1918 (Święcicki, 1971). 'Social security' was contrasted with 'social insurance', the former being wider in scope and not only departing from the actuarial principles but also with a classical catalogue of social risks (Święcicki, 1971). This broader approach to social policy became even more profound during the 1970s, when in the declaration of the party leaders, social policy was proclaimed as equally important as economic policy, and aimed at meeting 'citizens' needs' (Balicka-Kozłowska, 1975). Therefore, 'social planning' was to gain equal status with regard to economic planning (an aim that was present in Hungary) and received its own recognition and importance from the beginning of the 1970s, with Edward Gierek's term in office as the party leader (Piotrowski, 1979).

The language of 'needs' was accompanied, for the first time, by calls for the 'rationalisation' of social policy as a requisite for an increase in the 'efficiency of work' (PiZS, 1972). For example, the argument about the 'rationalisation of female employment' justified the introduction of longer maternity leaves (Jakubowicz, 1971). In a similar manner, 'efficiency' (that is, the withdrawal of mothers with small children from the workforce) justified the introduction of paid, three year long maternity leave in 1969 in Hungary (Szikra, 2011). In contrast to the Stalinist period, female employment started to be treated as 'complementary to that of men' (Jakubowicz, 1971). At the same time, faced by the looming economic crisis (especially the food crisis), the socialist state shifted its attitude with regard to private farmers. Even though still treated worse than industrial workers or those employed in collectivised agriculture, private farmers gained new social rights, including a separate pension system. In this way private farmers became (similarly to female workers) treated as 'complementary' to the socialist mode of economic production (Polakowski, 2010). Finally, important changes took place with regard to the name of central administration bodies: in 1960 the Ministry of Labour and Social Affairs was closed down and, instead, the Committee for Wages and Labour was established.The Ministry of Wages, Labour and Social Policy (polityka socjalna) was established in 1972 (Rybicki, 1978), with the word 'wages' disappearing from its title in 1987. 
Alongside the extension of social rights, research into inequalities emerged in Hungary during the mid-1960s (Ferge et al, 1966). However, the words 'poverty' or 'poor' were carefully avoided: when the first representative research on the Roma minority was carried out in 1971, the leading sociologist István Kemény had to leave the country for raising the issue of the poverty of the Roma (Kemény, 1976). Other researchers used expressions like 'low income' or 'disadvantaged' (hátrányos helyzetú). One important study in the mid-1980s defined the term 'social inclusion disorder'([társadalmi beilleszkedési zavar -TBZ), a label resembling a psychiatric classification and referring to marginalised families where certain 'deviancies' caused the 'dysfunctional working of the family' (Dús, 1986). When the underground organisation 'Fund to Help the Poor' (Szegényeket Támogató Alap - SZETA) was created in the early 1980s, its members were persecuted by the police for the open usage of the word 'poor', which was seen as a critique of the state socialist system in itself (Pik, 2001). The official discourse still insisted that poverty could only exist in capitalist societies.

Polish experts also noted a growing discrepancy between, on the one hand, the official rhetoric of the equality of socialist society and, on the other, increasing inequalities and deprivation among benefit recipients and certain groups of workers. Several studies on poverty existed, but were never published, and, when talking about poverty, official documents only used euphemisms such as 'shortage of goods' (niedostatek) (Rakowski, 2009). The need to define minimum living standards as a benchmark for the assessment of living conditions was voiced by social policy experts as early as the 1970s. However, the demand to make them publicly available was only put forward by the independent trade union Solidarność in 1980 during its famous negotiations. The monetary value of the so-called 'social minimum' (minimum socjalne) was subsequently published (Tymowski, 2001). Together with the call for an official recognition of poverty, this revealed a failure of the Polish state to satisfy the needs of population (as articulated in the 1970s) and represented the protest against the primacy of economic policy over social goals (Zieliński, 1982).

At the same time, the 'rationalisation' approach was revived to limit the development of social policy for the purposes of 'not spending more than we produce' (Zieliński, 1982). Legislation was adopted in 1982 to deal with 'social parasitism' (pasożytnictwo społeczne), which mostly referred to those who avoided taking up employment (Szarfenberg, 2010). This was followed by the parliamentary resolution on 'fighting the phenomena of social pathology (patologia spoteczna) and 'enhancing the moral health of society' in 1986. In this way, the 
productivist approach and the moral exclusion of those who did not work reappeared in official public policy during the period of the decline of state socialism.

It should be noted that research exchange with the Western world was severely limited. Only a select group of Hungarian state bureaucrats and experts could attend international meetings (for example the ILO assembly) and conferences (such as meetings of demographers) from the late 1960s. Consequently, the language of social policy was not much affected by the 'Western' concepts of the welfare state and social security. Interestingly enough, there was almost no connection with other countries of the 'Eastern bloc' until this period either; however, the Soviet hegemony caused important semantic changes in the language of social policy. Expressions like 'council' (tanács - совет) and 'societal benefits' (társadalmi juttatások - социальные льготы) were translations borrowed from their Russian counterparts.

\section{Capitalist democracy after 1989}

Although the political and economic transition from the communist system to a capitalist democracy brought about major changes in social policy, certain important continuations can also be observed in these institutions (Inglot, 2008; Szikra and Tomka, 2009). Social insurance remained the dominant social policy area in both countries. A radical change in that system only occurred in 1997 in Hungary, with partial privatisation of the pension system (Müller, 1999; Orenstein, 2008), a move which was only recently reversed. Experts and stakeholders in social insurance and local social policy (for example heads of nurseries, social administrators of municipalities and others) remained in place. Thus, although decentralisation of social services and the increased role of social assistance may be considered paradigmatic changes, certain continuities in the way social problems have been dealt with and the language that has been used by administrators and experts can also be observed.

Transition in Central and Eastern Europe (also called 'transformation' or 'velvet revolution'), took different forms in Hungary and in Poland. The 'big bang' package ('Balcerowicz Plan') led to a 'shock economic therapy' in the early 1990s in Poland, leaving many people below the minimum income level. Unlike that in Hungary, the social policy strategy had been to compensate for the loss of income, not to prevent this situation. Therefore, after massive outlays, many costly programmes of income compensation were introduced, together with a generous unemployment benefit scheme. However, when faced with so many 
unemployed people after the big bang, the government decided to cut the previous generous unemployment scheme and put more emphasis on establishing effective programmes of social assistance. Most of the programmes were, therefore, aimed at the poorest and involved the principle of income testing. The first comprehensive legislation in Hungary, called the 1993 'Social Act', aimed at defining the boundaries of 'deservingness' for adults, as separate from the issue of children, who, by definition, became eligible for various forms of assistance through the 1997 Child Protection Act. Decentralisation of responsibility for social policy was most visible in the sphere of care services.

Issues previously considered as taboos could now be openly expressed in both countries. Poverty, unemployment and homelessness could be discussed in the media and scholarly journals. Social policy as a scientific discipline was reborn, and a Department of Social Policy and Social Work was created at Eötvös University of Sciences, Budapest, followed by several other departments in major universities all over the country. While foreign - especially UK - influence was important, the founders of the new discipline also looked back in time to the prewar examples of social work and social policy courses and took inspiration from them. ${ }^{8}$

Most importantly, together with the fall of state socialism and the introduction of a democratic regime, an opportunity appeared for the various meanings and understandings of social policy to develop. In Poland, though, the narrow understanding of social policy as 'polityka socjalna' continued. The new capitalist economy was contrasted with the communist (or socialist) policies. Social policy was required for alleviating poverty caused by the 'necessary costs of transformation'. The adjective 'social' in the narrow translation as 'socjalna' became synonymous with 'fiscal burden'. The road towards the 'Western', 'modern', 'capitalist' economy was somehow 'disturbed' by the need to provide welfare for the 'losers of transformation'. The term 'welfare state' was already in use during the period of state socialism, mostly when describing developments in the West and linked to social democracy and 'socially oriented' economies (Rysz-Kowalczyk, 2002). The new rhetoric, often used by market oriented economists such as Leszek Balcerowicz, presented the 'welfare state' as the result of Western 'prosperity' (dobrobyt) and so the term 'welfare state' was typically

8 The development of courses, the interlinked nature of social work and social policy, and the importance of fieldwork to both social workers and social policy students were elements of social work and social policy training that were already present in the very first social policy course of the University of Economics in 1942. 
translated as 'prosperity state' (państwo dobrobytu). According to such a line of argument, countries like Poland first 'need to get to the level of Western prosperity' and only then 'could we afford' to have a welfare state (Balcerowicz, 1997).

The newly (re)discovered term of 'social policy' has had two alternative meanings in Hungarian, which were used by the 'left' and the 'right' of the political spectrum, respectively. During the 1990s and mid-2000s the 'left' (the leading force of which was the post-communist Hungarian Socialist Party - MSZP) preferred an allencompassing meaning of social policy that included social insurance, social assistance, family policies and social services. FIDESZ - Young Democrats' Alliance-Hungarian Civic Union (a Liberal party that turned to the right in the mid-1990s and has become the leading Conservative force since then) and the smaller Christian Democratic Party (KDNP) aimed at narrowing the meaning of social policy to social assistance provided to the poor. The shift to the more limited meaning was striking when FIDESZ was in power between 1998 and 2002, and recently, since 2010. Family policy is explicitly differentiated from social policy according to the Conservatives, where the former is aimed at increased fertility of the middle class and the latter at the marginal assistance of the poor. Social insurance is also separated from social policy and has been administered by the Ministry of National Economy since 2010. The Ministry of Welfare was closed and a giant Ministry of Human Resources was created, where family policy is handled separately from 'social inclusion', this latter including the issue of the Roma and people with disabilities.

The term 'welfare state' or 'social state' has its own post-1990 history as well. In the early 1990s the Conservative government of the Hungarian Democratic Forum (MDF) defined its own role as promoting the building up of the Hungarian 'Soziale Marktwirtschaft' (szociális piacgazdaság), following the example of the newly unified Germany.Yet this ideal was soon forgotten, and has not been replaced by the Hungarian concept of 'welfare state' (jóléti állam).This term only exists as something that Hungary might reach in the (far) future, or as something that exists in wealthier parts of Europe. Only the short-lived Socialist Medgyessy government (2002-04) used the term to point out a relatively rapid change in the living standards of Hungarians when it called for a 'welfare change' in 2002. A similar attempt for paradigmatic shift was the Child Poverty Programme between 2006 and 2008; here the rhetoric of 'social investment' gained some ground for a short while.

Apart from these failed attempts, 'welfare systems' (jóléti rendszer) and - as they have frequently been called by economists - 'big systems of 
distribution' (nagy elosztó rendszerek) were contextualized as 'burdens' on the free market and obstacles for the Hungarian economy. Governments argued for a 'small state' (kis állam) and for retrenchment most of the time (apart from during election campaigns). The term 'social policy' became a difficult one: it could not easily (if at all) be integrated into everyday language because of its connotations of something that has to do with 'socialism' and 'politics'. The term 'social work' also fared ill, as it is connected to the word 'labour', which reminds people of the compulsion to labour under state socialism.

The dominance of a neoliberal discourse in the public approach to social policies was hard to break in Poland also. After 1989, consecutive governments tried to change this social policy language, but such discursive changes had no effect on actual policies. Jacek Kuroń, the first Minister of Labour and Social Policy after 1989, tried to 'explain' the reforms to the public by regular television appearances, where he famously wore a casual blue denim shirt (not a suit, like most of the other politicians and experts). Afterwards, the 'social democratic' (post-communist) governments of the mid-1990s declared a departure from austerity policies and hardship that 'people could no longer bear' (Inglot, 2008).

When justifying cuts in social policy spending, phrases such as 'laziness' and 'learned helplessness' remained reference points. Polish intellectual circles invented and/or popularised terms like 'homo sovieticus', 'learned helplessness', or 'civilisational incompetence' (Ferge, 2008). For example, 'homo sovieticus' was a representation of the type of person who was raised in the socialist ('communist', or 'Soviet') system, where the 'paternalistic' state was 'doing everything for him/her' and in this way made him/her passive and 'infantile' (Sztompka, 2000). The 'homo sovieticus' was, according to the argument, completely 'unprepared' for the conditions of competition, where first and foremost the will to work and to perform were required in the new, capitalist and 'civilised' order (Hnatiuk and Kołodziejska, 2012). Thus, social policy instruments are constantly 'abused' by the groups displaying a 'demanding stance', because they are unable to 'adjust' to the new conditions.

Preparing for accession to the European Union (EU) further complicated the picture. ${ }^{9}$ Hungary started to participate in EU financed programmes and adjust its legal system at the end of the 1990s, when it also had to learn EU jargon. The term 'equal opportunities' (esélyegyenlöség), for example, was disseminated during this process. But as 'gender equality' or 'equal opportunities for people with disabilities

$9 \quad$ Hungary and Poland entered the EU in 2004. 
[[this now reads as 'people with minorities', which is grammatically incorrect; do you mean 'people from minority ethnic communities'?] and minorities' remained mainly on paper, the expressions describing such phenomena did not become part and parcel of mainstream social policy language. It is telling that no single word for 'gender' has emerged in Hungarian or Polish: in both languages, the notion of 'gender' is only understood when translated by a longer chain of words describing its meaning, which makes it hard to use expressions like 'gender roles', 'gender order', and 'gendered institutions'.

Concepts like 'social inclusion' (társadalmi befogadás) and 'exclusion' (társadalmi kirekesztés) could not easily be translated into Hungarian: prominent social policy experts lamented this situation on the eve of EU accession (Ferge, 2002; Szalai 2002). The EU tried to influence national social policy through the new terminology with limited success. Documents like the 'National Action Plan for Social Inclusion' were prepared by bureaucrats but actual discrimination against women, the Roma, people with disabilities and migrants continued over time.

In Poland, neoliberal discourse was partially strengthened by the workfare orientation of EU policies aimed at improving 'employability'. The somewhat bureaucratic language of EU social policy has also been introduced primarily via the use of the European Social Fund. Interestingly, the right-wing, Eurosceptic and Conservative Party 'Law and Justice' (Prawo i Sprawiedliwość 'PiS') was in fact one of the few political organisations that openly criticised the market orientation of the post-1989 Polish transformation and postulated stronger state engagement in economic and social policy. It was in 2005 that the first Prime Minister of the Conservative Coalition changed the name of the Ministry of Labour and Social Policy to one which included the broader translation of the term 'social policy' (polityka spoteczna), removing the 'old' adjective 'socjalna' that had a bad connotation and was mostly used when talking about social programmes for poor people.

Although civil control over social policy increased during the first half of the 1990s in Hungary, and even if 'self-governance' of the social insurance system was created to include the participation of employers and workers, we now see a gradual reversal of the process. Nationalisation recently carried out by the Conservative government ofViktor Orbán is also reflected in the change of social policy language. 'Protection', reflecting the language of both the 1930s and the 1980s, became a key concept in this context. For example, when private pension savings were confiscated by the state in 2011, the person responsible for the process was named 'Commissioner of the Protection of Pensions' (nyugdijvédelmi biztos). The recent suggestion by the Prime Minister to build a 'society based on work' instead of a 'welfare state' suggests that 'work' and 'welfare' are opposing notions, where 'work' 
is a positive force, strengthening society, whereas 'welfare' is defined as 'social assistance' for those who are unable to work, and thus only impose a burden on the 'working' society. ${ }^{10}$

\section{Conclusion}

The goal of this chapter was to trace the shifting meaning of social policy vocabulary in Hungary and Poland, two countries that experienced state socialism. We began our analysis with developments in the 19th century and continued to the interwar period, when the formation of the nation-states of both Poland and Hungary started and in which social policy played a central role. In the 1920s and 1930s, the term 'social policy' was used in Poland in a broader sense as polityka spoteczna, where społeczny means 'social', and where social policy was driven by intellectuals from socialist circles linked to international initiatives and networks. The term 'social policy' developed during the Dual Monarchy in Hungary, and by the 1930s 'social state' or even 'active state' became central. These notions referred to the state's increased intervention in the social affairs and the behaviour of its citizens. During state socialism, these terms lost their importance as social policy and social work became 'inexistent': central economic planning was supposed to eradicate poverty and all other social problems. However, a central pillar of social policy - that is, social insurance - continued to exist. The language of social policy discourse was ideologically loaded from the outset of the transformation to a market economy in both countries. After the fall of communism in Poland the term 'social policy' was understood as 'socialist' policy and hence had negative connotations. The dominating discourse was to depart from the period of state socialism. Simultaneously, there was the discourse of 'homo sovieticus' 'civilisational incompetence' - that justified social policy cuts. However, social policy and social work have been re-established as academic disciplines in both countries and thus created their new language, with intended references to the interwar period.

The term 'welfare state' has been understood as a state of prosperity with generous social provisions and thus it has been referred to in connection with 'Western' or 'Northern' countries 'that can afford it'. The prevalence of the rule of the market over social policy is rarely contested in Hungary and Poland and the term 'social policy'

10 Viktor Orbán: Nem jóléti állam, hanem munka alapú társadalom épül. (We do not build a welfare state; we build a society based on work.) 18 October, 2012. www.fidesz.hu/index.php?Cikk=185467 
is frequently equated with 'poor policies' or 'social assistance'. Social policy vocabulary thus often describes benefit recipients as 'immature' and 'passive,' delegitimising the very existence of such programmes. EU related social policy language seems to be going more in the direction of actually supporting the idea of individual responsibility, though with the European Social Fund absorption process, at least gender equality and equal opportunity slogans are gaining some ground in both countries.

\section{References}

Albert,A. (1989) Najnowsza Historia Polski.London:Polonia Book Fund. A Magyar Szocialista Munkáspárt központi Bizottságának beszámolója (1993). In: A Magyar Szocialista Munkáspárt VIII. kongresszusa. Budapest:Kossuth Könyvkiadó.

Általános Munkás- Betegsegélyzö Pénztár. Jelentés a Pénztár forgalmáról és müködéséról. 1870-1898. Táblázatos kimutatásokkal és statisztikai adatokkal. Budapest, 1899.

Arató,A. (1993) Forradalom, restauráció és legitimáció.Az államszocializmusból való átmenet ideológiai problémái Politikatudományi Szemle, 3, 5-44.

Augusztinovics, M. (ed.) (2000) Körkép reform után. Tanulmányok a nyugdírrendszerról. Budapest: Közgazdasági Szemle alapítvány.

Balcerowicz, L. (1997) Socializm, kapitalizm. Szkice z przełomu epok. Wydawnictwo Naukowe PWN.

Balicka-Kozłowska, H. (1975). Niektóre problemy opiekii pomocy społecznej. Praca i zabezpieczenie spoleczne xvii(12).

Bicskei, É. (2006) 'Our Greatest Treasure, the Child': The Politics of Child Care in Hungary, 1945-1956'. Social Politics, Vol. 13, Nr.2.

Bódy, Z. (2001) 'A 'szociális kérdés' kezelésének alternatívái a XIX. század végén. Az 1891-es kötelező betegbiztosítási törvény keletkezése.' In.: Korall, 2001. September.

Bódy, Z. (2011) Az ipari munka társadalma - Szociális kihívások, liberális és korporatív válaszok Magyarországon a 19. század végétôl a második világháborúig. Budapest: Argumentum.

Chumiński, J. (2010) Mentalne bariery rozwoju gospodarczego PRL. Modernizacja czy pozorna modernizacja? Społeczno-ekonomiczny bilans PRL 1944-1948. Gajt, Wrocław: 92-232.

Czubiński, A. (1978) 'Polska w okresie dwudziestolecia miedzywojennego'. Dzieje Polski. J. Topolski (ed.), Warsawa: Polskie Wydawnictwo Naukowe, 612-778.

Daszyńska-Golińska, Z. (1906) Teoretyczne podstawy polityki społecznej $w$ XIX stuleciu. Warszawa: Nakładem Księgarni Naukowej. 
Dús, Á. (ed.) (1986) Társadalmi beilleszkedési zavarok. Budapest: Kossuth Kiadó.

Ecseri, L. (1884) A munkássegélyezés ügye Magyarországon. Pesti Könyvnyomda Rt., Bp.

Esztergár, L. (1941) 'Társadalomépítés.' Sorsunk, 1-2. Pécs, Dunántúl Pécsi Egyetemi Könyvkiadó és Nyomda Rt.

Esztergár, L. \&Somogyi, F. (1940) A magyar szociálpolitika feladatai: A vármegyei szociális tanácsadók és közjóléti elóadók pécsi országos szociálpolitikai értekezletén elhangzott elöadások. Pécs, Kultúra.

Ferge, S. e.a. (1966) Társadalmi rétegzödés Magyarországon: 15000 háztartás 1963. évi adatai. Budapest: KSH.

Ferge, Z. (1986) Fejezetek a szegénypolitika történetéból. Budapest: Magvető Kiadó.

Ferge, Z. (2002) ‘Az EU és a kirekesztés.' In. Esély 2002. 6. 3-13.

Ferge, Z. (2008) Is there a specific East-Central European welfare culture? W. van Oorschot e.a. (eds.) Culture And Welfare State. Values and Social Policy in Comparative Perspective, London: Edward Elgar,141-161.

Heller, F. (1947) Közgazdaságtan. II. kötet. Alkalmazott közgazdaságtan. Budapest: Mérnöki Továbbképző Intézet kiadása.

Hnatiuk, M. \& M. Kołodziejska (2012) Pożegnanie z homo sovieticus: próba empirycznej weryfikacji kategorii oraz analiza jej obecności w socjologicznym dyskursie o transformacji. Maciej G. \& P. Sadura (eds.) Style życia i porządek klasowy w Polsce, Warszawa: Scholar.

Horváth, S. (2012) Két emelet boldogság. Mindennapi szociálpolitika Budapesten a Kádár-korban. Budapest: Napvilág kiadó.

Indoklás. (1940) XXIII. törvénycikk az Országos Nép- és Családvédelmi Alapról. Magyar törvénytár, 1941, Franklin, Budapest.

Inglot, T. (2008) Welfare States in East Central Europe, 1919-2004, Cambridge: Cambridge University Press.

Jackowiak, C. (1991) Po drugiej wojnie swiatowej: kierunki rozwoju ubezpieczen spolecznych. Rozwoj ubezpieczen spolecznych na ziemiach polskich, edited by C. Jackowiak. Ossolineum, Wroclaw.

Jakubiec, D. (2007) Pierwsze polskie instytucje ubezpieczen spolecznych. Zarys historii i ustroju. Warszawa: Zaklad Ubezpieczen Spolecznych.

Jakubowicz, M. (1971) Racjonalne zatrudnienie a praca kobiet. Praca $i$ zabezpieczenie spoleczne xiii(4)

Kemény, I. (1976) Beszámoló a magyarországi cigányok helyzetével foglalkozó, 1971-ben végzett kutatásról. Budapest: MTA Szociológiai Intézet.

Kornai, J. (1980) Economics of Shortage. Amsterdam: North-Holland, 1980.

Lackó, M. (1961) Ipari munkásságunk összetételének alakulása 1867-1949. Budapest:Táncsics. 
Magyary, Z. (1936) A nemzeti szocialista községi közigazgatás. Különlenyomat aVárosi Szemle 22. évfolyamából, Budapest.Magyary, Z. (1939) 'A közigazgatás és az emberek. Eredmények és tanulságok.' In. Magyary, Zoltán and Kiss, István. 1939. A közigazgatás és az emberek. Dunántúl, Budapest. 353-373.

Magyary, Z. (1939) 'Közigazgatás - szociális közigazgatás.' In. Közigazgatási továbbképző tanfolyam. Budapest, Állami Nyomda, 1939. 103-110.

Magyary,Z.(1941) (ed.) A szociális vármegye. A Komárom vármegyei Közjóléti és Gazdasági Szövetkezet múködése. Magyar Közigazgatástudományi Intézet, Budapest. 24-41.

Müller, K. (1999) The Political Economy of Pension Reform in CentralEastern Europe. Cheltenham, Northampton.

Munkaügyi Minisztérium, Szociálpolitikai Főosztály (1960) A szociálpolitikai intézkedések 20 éves távlati terve. 'Szigorúan Titkos.' Hungarian National Archives, XIX-C-5, 147. doboz.

Orenstein, M.A. (2008) Privatizing Pensions:The Transnational Campaign for Social Security Reform. Princeton University Press.

Orlewicz, T. (1947) Polityka społeczna Polski w obliczu Planu Gospodarczego. Praca i opieka spoleczna 1 (XXI):27-35.

Orłowski, A. (1912) Ubezpieczenia robotnicze $w$ dumie państwowej. Warszawa: Skład Główny w Księgarni G. CenterSzwera i S-ki.

Orwell, George (1949) Nineteen Eighty-Four (1984). Secker and Warburg, London.

Pető, I. \& Szakács, S. (1985) A hazai gazdaság négy évtizedének története 1945-1985. I.kötet. Budapest: Közgazdasági és Jogi Könyvkiadó.

Pik, K. (2001) A szociális munka története Magyarországon, 1817-1990. Budapest: Hilscher Rezső Szociálpolitikai Egysület.

Piotrowski, J. (1979) 35 lat społecznego rozwoju. Praca i zabezpieczenie

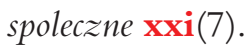

PiZS. (1972) Ministerstwo obietnic i nadziei. Praca $i$ zabezpieczenie spoleczne $\mathbf{x i v}(7)$.

Polakowski, M. (2010) The Institutional Transformation of Social Policy in East Central Europe. Poland and Hungary in Comparative and Historical Perspective. Maastricht: Boekenplan.

Radlińska, Helena. (1947) Zagadnienia opieki społecznej (Ze skrzyżowań teorii i praktyki). Praca i opieka spoleczna 4 (xxi):277-285.

Rakowski,T. (2009) Eowcy, zbieracze, praktycy niemocy. Warszawa: Słowo/ obraz terytoria.

Romsics, I. (1999) Hungary in the 20th Century. Budapest: Corvina Kiadó. 
Rybicki, Z. (1978) Administracje gospodarcza w PRL. Warszawa: Polskie Wydawnictwo Naukowe

Rysz-Kowalczyk (ed.). (2002) Leksykon polityki społecznej, Warszawa: Oficyna Wydawnicza Aspra-jr,.

Saád, J. (2000) Magyary Zoltán. Budapest: Új Mandátum.

Szabó, M. (2003) A diszkurzív politikatudomány alapjai. Elméletek és elemzések. Budapest, L'Harmattan Kiadó.

Szalai, J. (1985) 'A szociálpolitika nyelve- amit kifejez és amit eltakar.' In. Medvetánc 1984-1985. 4-1. 105-119.

Szalai,J. (1992) ‘A társadalombiztosítás érdekviszonyairól.' In: Szociológiai Szemle 2. szám. 27 - 43.

Szalai, J. (2002) „A társadalmi kirekesztődés egyes kérdései az ezredforduló Magyarországán.' [Some questions about social exclusion in Hungary at the turn of the Millenium.] In. Szociológiai Szemle 2002. 4. 34-50.

Szalai, J. (2007) Nincs két ország...? Budapest, Osiris Kiadó.

Szarfenberg, R. (2010) Marginalizacja i wykluczenie społeczne panorama językowo teoretyczna. R. Szarfenberg e.a. (eds.) Ubóstwo $i$ wykluczenie społeczne perspektywa poznawcza. Warszawa: Elipsa.

Szikra, D. (2004) 'The Thorny Path to Implementation: Bismarckian social insurance in Hungary in the late 19th century.' European Journal of Social Security, 2004,Vol. 6, Nr. 3, September, 255-272.

Szikra, D. (2009) 'Social Policy and Anti-Semitic Exclusion before and during World War II in Hungary. The Case of the Productive Social Policy.' In Hauss, G. \& Schulte, D.: Amid Social Contradictions. Towards a History of Social Work in Europe. Opladen and Farmington Hills: Barbara Budrich Publishers. 2009. 111-131.

Szikra, D. (2011) 'Tradition Matters: Child Care and Primary School Education in Modern Hungary.' In. Hagemann, K. et.al. (eds.) Child Care and Primary Education in Post-War Europe. New York and Oxford, Berghahn Books. 2011.

Szikra, D. (2012) 'Welfare Co-operatives' and social policy between the two World Wars in Hungary.' In. Hilson, Mary e.a. (eds.). Co-operatives and the Social Question: The Co-operative Movement in Northern and Eastern Europe, 1880-1950. Cardiff : Welsh Academic Press, 153-167. Szikra, D. and B.Tomka. (2009). 'Social Policy in East Central Europe. Major Trends in the 20st Century.' In Cerami,A. \& P.Vanhuysse (eds.) Post-Communist Welfare Pathways:Theorizing Social Policy Transformations in Central and Eastern Europe. Basingstoke: Palgrave Macmillan.

Święcicki, M. (1971) Ubezpieczenia społeczne a prawo pracy. Praca $i$ zabezpieczenie spoleczne xiii (8-9). 
Sztompka, P. (2000) Trauma wielkiej zmiany : społeczne koszty transformacji. Instytut Studiów Politycznych Polskiej Akademii Nauk, Warszawa.

Tomka, B. (2003) Szociálpolitika a 20. századi Magyarországon európai perspektívában. Budapest, Századvég Kiadó.

Tymowski, A. (2001) Z perspektywy czasu: początki 'minimum socjalnego'. Polityka społeczna vol. 11-12/2001.

Zalewski, D. (2006) Opieka i pomoc społeczna. Dynamika instytucji. Wydawnictwa Universytetu Warszawskiego, Warszawa

Zawadzki, W. (1927) Polska polityka socjalna a gospodarstwo społeczne. Towarzystwo Ekonomiczne, Kraków.

Zieliński, T. (1982) Podstawowe problmy reformy ubezpieczeń społecznych w PRL. Praca $i$ zabezpieczenie spoleczne xxiv(4). 